\title{
AKUISISI BAHASA ARAB PADA TATARAN GRAMATIKA DAN RASA BAHASA BAGI PEMBELAJAR NON ARAB
}

\author{
Mukhlis Anshari \\ kalimantankita@gmail.com
}

\begin{abstract}
Acquisition of Arabic language at the level of language sense that the acquisition of language that has reached the stage of intact understanding of the context of the meaning of each word and phrase delivered by the native speakers both verbally and non verbally. Verbally, it means that a learner understands what the native speakers say. While the meaning of non vebal, the language conveyed by the native speakers in the form of papers, in the form of books or literary manuscripts.
\end{abstract}

Keyword: Acquisitions, Grammar, Language

\begin{abstract}
Abstrak
Akuisisi bahasa Arab pada tataran rasa bahasa yaitu pemerolehan bahasa yang sudah mencapai pada tahap pemahaman utuh tentang konteks makna setiap kata dan ungkapan yang disampaikan oleh para penutur asli baik secara verbal maupun non verbal. Secara verbal, maksudnya yaitu seorang pembelajar memahami apa yang disampaikan oleh para penutur asli secara lisan. Sedangkan yang dimaksud dengan non vebal, yaitu bahasa yang disampaikan oleh para penutur asli dalam bentuk karya tulis, berupa buku-buku atau naskah sastra.
\end{abstract}

Kata Kunci: Akuisisi, Gramatika, Rasa Bahasa

\section{Pendahuluan}

Bahasa Arab merupakan salah satu bahasa yang mendunia dan mempunyai karakteristik khusus, baik pada tataran gramatika maupun pada tataran makna.

Terlebih lagi bahwa merupakan bahasa agama yaitu sebagai bahasa kitab suci AlQur'an. Posisi ini menjadikan bahasa Arab sebagai bahasa yang multi dimensi.

Seseorang yang ingin mempelajari suatu bahasa secara umum biasanya mempelajari gramatika bahasa tersebut baik yang terkait dengan gramatika sintaksisnya maupun yang terkait dengan gramatika morfologisnya.

Akan tetapi sebenarnya seseorang tidak mungkin dapat memahami secara utuh suatu bahasa tanpa mempelajari, melatih, mendalami "rasa bahasa" yang dimiliki tiap bahasa. Tentu hal ini terkait dengan makna dengan berbagai macam dan konteksnya yang tidak bisa lepas dari budaya para penuturnya.

Bahasa Arab merupakan salah satu bahasa yang mana setiap katanya mempunyai banyak makna sesuai konteks keadaan para 
penuturnya. Sebagaimana sifat umumnya bahasa, bahasa Arab juga mengalami perkembangan makna dari masa ke masa.

Rasa bahasa tersebut bisa juga disebut sebagai proses memahami bahasa tertentu sebagaimana yang dituturkan dan dipahami oleh para pemilik asli bahasa tersebut. Rasa bahasa tersebut bisa di dapat dari interaksi langsung dengan native speakerl penutur asli dari bahasa tersebut secara berkesinambungan dan intensif, ataupun dari hasil pengecapan hasil karya sastra yang dihasilkan oleh para penutur asli. Tentunya interaksi langsung dengan para penutur asli secara intensif jauh lebih nampak hasilnya dari pada hanya berusaha memahami dari hasil karya sastra mereka.

\section{Pengertian Akuisisi Bahasa}

Dalam kamus besar bahasa indonesia pemerolehan diartikan sebagai proses, cara atau perbuatan memperoleh. Pemerolehan bahasa adalah proses yang berlangsung didalam otak anak-anak ketika dia memperoleh bahasa pertamanya atau bahasa ibunya. Istilah pemerolehan dipakai untuk padanan istilah inggris acquisition, yakni proses penguasaan bahasa yang dilakukan oleh anak secara natural pada waktu dia belajar bahasa ibunya (native language).

Bahasa yang diperoleh bisa berupa vokal yakni pada bahasa lisan atau bunyi ujaran dan bisa berupa isyarat. Manusia memiliki warisan biologi yang sudah dibawa sejak lahir berupa kesanggupannya untu berkomunikasi dengan bahasa khusus manusia dan itu tidak ada hubungannya dengan kecerdasan atau pemikiran. Kemampuan berbahasa hanya sedikit korelasinya terhadap IQ manusia.

Kemampuan berbahasa anak yang normal tidak sama dengan anak-anak yang cacat. Kemampuan berbahasa sangat erat hubungannya dengan bagian-bagian anatomi dan fisiologi manusia, seperti bagian otak tertentu yang mendasari bahasa dan topografi korteks yang khusus untuk bahasa. ${ }^{1}$

Sedangkan menurut Soenjono istilah "pemerolehan" merupakan padanan kata acquisition yakni proses penguasaan bahasa yang dilakukan oleh anak secara natural pada waktu dia belajar bahasa ibunya. Istilah ini juga berbeda dengan pembelajaran (learning) dalam pengertian, proses ini dilakukan dengan tatanan formal, belajar di kelas dan diajar oleh seorang guru. Dengan demikian maka proses dari anak yang belajar menguasai bahasa ibunya adalah pemerolehan, sedangkan proses dari orang yang belajar di kelas adalah pembelajaran. ${ }^{2}$

Memang banyak teori yang mendefinisikan dan mengungkapkan tentang

${ }^{1}$ Halijah dan Abd Hamid, Bagaimana Manusia Memperoleh Bahasa, (Jakarta: Pelita Bahasa, 2006), h. 29

2 Soenjono Dardjowidjojo, Psikolinguistik, (Jakarta: Yayasan obor Indonesia, 2003), h. 225 
makna pemerolehan bahasa secara umum, akan tetapi di sini penulis merasa tidak perlu memaparkannya karena memang secara umum sudah banyak yang mengulas dan membahasnya.

Jadi secara umum pemerolehan bahasa merupakan proses di mana seeorang mendapatkan dan mencerna suatu bahasa hingga akhinya dapat menggunakannya baik secara verbal maupun non verbal.

\section{Akuisisi Bahasa Arab Pada Tataran Gramatika}

Akuisisi bahasa Arab sebagai bahasa kedua setelah bahasa ibu, tidak terlepas dari kedudukan bahasa Arab itu sendiri sebagai bahasa agama umat Islam. Apalagi negara Indonesia merupakan negara dengan jumlah penduduk muslim terbanyak.

Secara umum bahasa Arab dipelajari hampir di setiap lembaga pendidikan yang berbasis agama bahkan sampai di perguruan tinggi, hanya saja kebanyakan masyarakat Indonesia mempelajari bahasa Arab hanya sampai pada tataran gramatikanya.

Gramatika bahasa Arab secara umum dibagi menjadi dua macam yaitu gramatika yang terkait dengan peraturan baris atau huruf dari setiap akhir kata dalam bahasa Arab atau yang lebih dikenal dengan ilmu nahwu, dan yang kedua adalah gramatika yang membahas dan mempelajari tentang komposisi huruf dari setiap kata beserta berbagai bentuk dan perubahannya, atau yang lebih dikenal dengan ilmu sharaf. Meskipun sebenarnya gramatika bahasa Arab itu banyak dan masing-masing mempunyai ranah bahasan tersendiri.

Paradigma yang ada bahwa proses akuisisi bahasa pada tataran gramatika bahasa Arab ini adalah paradigma yang paling umum yang didapat oleh para pembelajar bahasa Arab di setiap jenjang pendidikan, khususnya dari tingkat sekolah dasar atau ibtidaiyyah, madrasah tsanawiyah, dan madrasah aliyah. Bahasa Arab hanya dipahami sampai tataran gramatikanya saja, sehingga saat berhadapan langsung dengan penutur bahasa Arab asli, bahasa yang digunakan oleh pelajar di Indonesia secara umum kurang dipahami oleh para penutur asli.

\section{Akuisisi Bahasa Arab Pada Tataran Rasa Bahasa}

Akuisisi bahasa Arab pada tataran rasa bahasa yaitu pemerolehan bahasa yang sudah mencapai pada tahap pemahaman utuh tentang konteks makna setiap kata dan ungkapan yang disampaikan oleh para penutur asli baik secara verbal maupun non verbal. Secara verbal, maksudnya yaitu seorang pembelajar memahami apa yang disampaikan oleh para penutur asli secara 
lisan. Sedangkan yang dimaksud dengan non vebal, yaitu bahasa yang disampaikan oleh para penutur asli dalam bentuk karya tulis, berupa buku-buku atau naskah sastra.

Menurut Abdul Majid dalam bukunya 'Ilmul Lughah An-Nafsy' membagi pemerolehan bahasa itu ke dalam dua kategori yaitu akuisisi bahasa secara verbal dan akuisisi bahasa non verbal, akan tetapi yang dimaksud dengan akuisisi bahasa non verbal yaitu proses akuisisi bahasa dari seorang anak yang masih sangat muda sekali atau masih bayi, dia memperoleh bahasa dengan diawali dengan interaksi suara tangisan dan berbagai gerakan dari orang-orang di sekelilingnya yang mana belum bisa dikategorikan sebagai bahasa verbal yang dipahami oleh orang yang sudah dewasa. ${ }^{3}$

Rasa bahasa itu sendiri adalah proses "pengecapan bahasa" atau yang lebih dikenal dalam istilah Arabnya dengan "At-Tadzawwuqu Al-Lughawi. Orang yang sampai pada tataran ini dapat berinteraksi secara baik dengan para penutur asli bahasa Arab. Jadi akuisisi bahasa Arab pada tahap ini merupakan tahap dimana seseorang memahami berbagai makna yang terkandung dalam setiap ungkapan yang disampaikan oleh

\footnotetext{
${ }^{3}$ Dr. Abdul Majid Sayyid Ahmad Mansur, Ilmul Lughah An-Nafsy, (Riyadh: 'Imadatu Syu'unil Maktabat, 1982) h. 147
}

para penutur asli. Makna berbagai ungkapan tersebut tentu tergantung pada berbagai konteks yang berbeda.

Taufiqurrahman dalam bukunya 'Leksikologi Bahasa Arab' memaparkan berbagai macam makana sebagai berikut: ${ }^{4}$

\section{Makna Leksikal}

Makna leksikal adalah makna yang sebenarnya, makna yang sesuai dengan hasil observasi indera kita, maka ia bersifat apa adanya, atau makna yang ada di dalam kamus. Misalnya, leksem 'kuda' memiliki makna leksikal sejenis binatang berkaki empat yang biasa dikendarai.

\section{Makna Gramatikal}

Makna gramatikal baru ada kalau terjadi proses gramatikal seperti afiksasi, reduplikasi, komposisi atau kalimatisasi. Umpamanya, dalam proses aplikasi prefiks ber- dengan 'baju' melahirkan makna gramatikal mengenakan atau memakai baju.

\section{Makna Kontekstual}

Makna kontekstual adalah makna sebuah laksem atau kata yang berada dalam suatu konteks. Misalnya makna 'kepala' pada kalimat berikut: a. Rambut di kepala nenek belum ada yang putih, b. Sebagai kepala sekolah dia harus menegur murid itu.

\footnotetext{
${ }^{4}$ Dr. H.R. Taufiqurrahman, M.A., Leksikologi Bahasa Arab, Cetakan ke-II, (Malang: UIN-Maliki Press, 2015), h. 60-67
} 
Terkait dengan makna kontekstual, Farid 'Iwadh Haidar memaparkan pembagian makna kontekstual menurut K. Ammer yaitu: ${ }^{5}$
a. Konteks Bahasa (Linguistic Context)
b. Konteks Emosi (Emotional Context)
c. Konteks Situasi/ Keadaan (Situational Context)
d. Konteks Budaya (Cultural Context)

\section{Makna Referensial}

Sebuah kata disebut bermakna referensial kalau ada referensinya, atau acuannya. Kata-kata seperti 'kambing' disebut bermakna referensial kalau ada referensinya, atau acuannya. Kata-kata seperti 'jika', 'meskipun' adalah kata-kata yang tidak bermakna referensial karena kata-kata itu tidak mempunyai referens, atau disebut juga kata bermakna 'non referensial' (memiliki makna tetapi tidak memiliki acuan).

\section{Makna Denotatif}

Makna denotatif adalah makna asli, makna asal, atau makna sebenarnya yang dimilikioleh

\footnotetext{
5 Dr. Farid 'Iwadh Haidar, 'Ilmu AdDalaalah, (Mesir: Maktabatun Nahdhah AlMishriyyah, 1999), h. 158
}

sebuah kata. Umpamanya, kata kurus bermakna denotatif yang mana artinya 'keadaan tubuh seseorang yang lebih kecl dari ukuran normal'.

\section{Makna Konotatif}

Makna konotatif (makna majazi) adalah makna lain yang ditambahkan pada makna denotatif tadi yang berhubungan dengan nilai rasa dari orang atau kelompok. Misalnya kata 'kurus' berkonotasi makna netral, sedangkan 'ramping' bermakna kurus yang indah, sedangkan 'kerempeng' bermakna kurus yang tidak indah.

\section{Makna Konseptual}

Makna konseptual adalah makna yang dimiliki oleh sebuah leksem terlepas dari konteks atau asosiasi apapun. Kata 'kuda' memiliki makna konseptual sejenis binatang berkaki empat yang biasa dikendarai.

\section{Makna Asosiatif}

Makna asosiatif adalah makna yang dimiliki sebuah leksem atau kata bahasa. Misalnya, kata 'melati' berasosiasi dengan sesuatu yang suci atau kesucian.

\section{Makna Kata}

Makna kata adalah makna yang masih bersifat umum, kasar dan tidak jelas. Makna 'tangan' dan 'lengan' merupakan kata yang bersinonim dan akan dapat dipahami dalam konteks sebuah kalimat tertentu. 


\section{Makna Istilah}

Yang disebut istilah adalah yang mempunyai makna yang pasti, jelas dan tidak meragukan, meskipun tanpa konteks kalimat. Yang perlu diingat bahwa sebuah istilah hanya digunakan pada keilmuan atau kegiatan tertentu. Meskipun dalam perkembangan zaman, ada beberapa istilah yang akhirnya digunakan secara umum.

\section{Makna Idiom}

Idiom adalah satuan ujaran yang maknanya tidak dapat diramalkan dari makna unsurunsurnya, baik secara leksikal maupun secara gramatikal. Misalnya 'membanting tulang' bermakna 'bekerja keras'.

\section{Makna Pribahasa}

Berbeda dengan idiom yang maknanya tidak dapat diramalkan secara lesikal maupun gramatikal, maka yang disebut pribahasa memiliki makna yang masih dapat ditelusuri atau dilacak dari makna unsur-unsurnya. Misalnya ungkapan 'seperti anjing dan kucing' bermakna 'tidak pernah bisa akur'. Proses untuk sampai pada tingkat pengecapan rasa bahasa yang baik memerlukan waktu interaksi yang intensif dan kemampuan bersosialisasi dan beradaptasi yang baik dengan para penutur aslinya. Hal ini tidak bisa didapat secara instan, karena rasa bahasa itu didapat dari proses panjang yang berkesinambungan. Sehingga dengan kata lain, orang yang dengan akuisisi rasa bahasa yang tinggi adalah orang yang hampir tidak ada bedanya dengan para penutur bahasa asli itu sendiri.

Para pakar bahasa secara umum banyak yang berpendapat bahwa untuk tahap awal bahkan tahapan selanjutnya pun yang sangat membantu dalam proses penguatan rasa bahasa adalah keterampilan menyimak/ istima', karena setiap manusia pun sejak bayi belajar bahasa dengan cara menyimak.

Menurut Syaiful Mustofa, prinsipprinsip dalam pembelajaran istima' dalam hubungannya dengan latihan mendengarkan untuk pemahaman ini perlu diperhatikan halhal berikut: ${ }^{6}$

1. Pendengar menerima informasi melalui rangkaian bunyi bahasa dengan susunan nada dan tekanan penempatan persendian (juncture). Perubahan susunan unsur bunyi dapat mengubah hubungan antar bagian kalimat atau arti kalimat secara keseluruhan. Kita sering menjumpai kalimat tanya yang bentuk dan susuman katanya sama dengan kalimat berita, namun berbeda karena lagu kalimat yang dipakai Dalam

6 Syaiful Mustofa. Strategi Pembelajaran Bahasa Arab Inovatif. (Malang: UIN-Maliki Press, 2011), h. 126-127 
pelajaran menyimak hendaknya dipupuk kemampuan siswa untuk menafsirkan makna kalimat melalui unsur-unsur bunyi.

2. Dalam tutur pembicaraan atau dalam teks yang dilisankan, biasanya terdapat gagasan pokok dan gagasan penunjang. Siswa hendaknya dilatih untuk dapat membedakan gagasan pokok dari gagasan sampingan, contoh dan ilustrasi. Misalnya dengan mengamati ungkapan petunjuk peralihan, seperti dalam bahasa Arab: ل أن, للألك, رغم أن, لأنه dan sebagainya.

3. Dalam memilih teks lisan hendaknya guru memperhatikan usia dan minat siswa, kosakata yang dimiliki siswa, tingkat kematangan dan kecepatan siswa dalam mengikuti teks lisan.

4. Kecepatan yang wajar tentu merupakan tujuan akhir pelajaran menyimak ini, tetapi untuk tahaptahap permulaan tidak ada salahnya kalau ucapan diperlambat sedikit. Yang diperlambat bukan ucapan kata-katanya, tapi jedahnya yang diperpanjang. Penyajian teks lisan untuk tingkat-tingkat permulaan perlu diulang, kalau perlu sampai tiga kali.
5. Penggunaan alat peraga banyak sekali manfatnya dan dapat membantu mempercepat pengertian. Tapi ada kalanya alat peraga ini dengan sengaja tidak dipakai agar siswa tidak terlalu banyak menggantungkan diri pada isyarat yang diperolehnya dari alat peraga ini. Dengan kata lain, para siswa diharapkan memahami teks-teks lisan hanya dari isyarat yang diterimanya melalui gerbang telinga saja.

6. Untuk tingkat lanjut, situasi perlu dibuat mendekati situasi sehari-hari. Gangguan-gangguan seperti background musik atau suara orang lain yang sedang bercakap-cakap, perlu dengan sengaja dimasukkan dalam rekaman. Hal ini tentu memersulit usaha meinahami teks lisan yatig sedang disajikan, tapi itulah realitas dalam kehidupan sehari-hari.

7. Guru sebaiknya menuliskan kata-kata kunci sebelum pelajaran dimulai dan menjelaskan maknanya. Tentu saja tidak semua kata baru dapat dikatakan sebagai kata kunci dan dijelaskan kepada siswa, karena kesempatan untuk menerka arti kata dari hubungan kalimat perlu juga diberikan kepada mereka.

8. Guru hendaknya menyampaikan kepada siswa dengan jelas apa yang harus mereka kerjakan. Petunjuk yang jelas akan merangsang para siswa dan 
menambah semangat mereka untuk berusaha memahami teks lisan yang disajikan guru.

9. Untuk mengetahui sejauh mana pemahaman siswa terhadap apa yang didengarkannya, maka setiap materi yang disajikan hendaknya dilengkapi dengan pertanyaanpertanyaan.

10. Respon atau jawaban para siswa bisa bervariasi. Untuk tingkattingkat permulaan, jawaban bisa berupa: gambar-gambar, jawaban lisan dengan bahasa Indonesia. Untuk siswa tingkat menengah atau lanjutan, jawaban dalam bentuk lisan atau tulisan dengan bahasa Arab. Tapi perlu digaris bawahi bahwa tujuan utama bukan hakekat jawaban itu sendiri, tetapi pengertian yang ditunjukkan siswa terhadap teks lisan yang disajikan.

Setelah kemampuan menyimak ini sudah cukup terlatih, maka siswa atau siapa saja yang hendak mendalami lebih lanjut mengenai rasa bahasa Arab, maka hendaknya dia mempelajari karya-karya para penutur asli di bidang sastra. Akan tetapi sebelum mempelajari karya utuh sebuah karya sastra Arab, sebaiknya dia harus mendalami terlebih dahulu ilmu Balaghah, karena ilmu tersebut mencakup berbagai pola ungkapan dan penjelasan detail dari contoh-contoh sederhana sampai contoh yang kompleks tentang ungkapan-ungkapan indah dari para penutur bahasa Arab asli. Sehingga dengan demikian akan mempermudah dan menjadikan proses akuisisi rasa bahasa Arab menjadi lebih efektif dan terarah.

\section{Simpulan}

Pemerolehan bahasa adalah proses yang berlangsung didalam otak anak-anak ketika dia memperoleh bahasa pertamanya atau bahasa ibunya. Istilah pemerolehan dipakai untuk padanan istilah inggris acquisition, yakni proses penguasaan bahasa yang dilakukan oleh anak secara natural pada waktu dia belajar bahasa ibunya (native language).

Gramatika bahasa Arab secara umum dibagi menjadi dua macam yaitu gramatika yang terkait dengan peraturan baris atau huruf dari setiap akhir kata dalam bahasa Arab atau yang lebih dikenal dengan ilmu nahwu, dan yang kedua adalah gramatika yang membahas dan mempelajari tentang komposisi huruf dari setiap kata beserta berbagai bentuk dan perubahannya, atau yang lebih dikenal dengan ilmu sharaf. Meskipun sebenarnya gramatika bahasa Arab itu banyak dan masing-masing mempunyai ranah bahasan tersendiri.

Akuisisi bahasa Arab pada tataran rasa bahasa yaitu pemerolehan bahasa yang sudah mencapai pada tahap pemahaman utuh tentang konteks makna setiap kata dan 
ungkapan yang disampaikan oleh para penutur asli baik secara verbal maupun non verbal. Secara verbal, maksudnya yaitu seorang pembelajar memahami apa yang disampaikan oleh para penutur asli secara lisan. Sedangkan yang dimaksud dengan non vebal, yaitu bahasa yang disampaikan oleh para penutur asli dalam bentuk karya tulis, berupa buku-buku atau naskah sastra.

Proses untuk sampai pada tingkat pengecapan rasa bahasa yang baik memerlukan waktu interaksi yang intensif dan kemampuan bersosialisasi dan beradaptasi yang baik dengan para penutur aslinya. Hal ini tidak bisa didapat secara instan, karena rasa bahasa itu didapat dari proses panjang yang berkesinambungan. Sehingga dengan kata lain, orang yang dengan akuisisi rasa bahasa yang tinggi adalah orang yang hampir tidak ada bedanya dengan para penutur bahasa asli itu sendiri.

\section{Daftar Pustaka}

Dardjowidjojo, Soenjono, Psikolinguistik, Jakarta: Yayasan obor Indonesia, 2003.

H.R. Taufiqurrahman, Dr., M.A., Leksikologi Bahasa Arab, Cetakan ke-II, Malang: UIN-Maliki Press, 2015.

Haidar, Farid 'Iwadh, Dr., 'Ilmu AdDalaalah, Mesir: Maktabatun
Nahdhah Al-Mishriyyah, 1999.

Halijah dan Abd Hamid, Bagaimana Manusia Memperoleh Bahasa, Jakarta: Pelita Bahasa, 2006.

Mansur, Abdul Majid Sayyid Ahmad, Dr., Ilmul Lughah An-Nafsy, Riyadh: 'Imadatu Syu'unil Maktabat, 1982.

Mustofa, Syaiful, Strategi Pembelajaran Bahasa Arab Inovatif, Malang: UINMaliki Press, 2011. 